\title{
Hubungan Jenis Kelamin, Stress, dan Kepuasan Mahasiswa Akuntansi terhadap Pembelajaran Daring di Masa Pandemi COVID-19
}

\author{
Sakina Nusarifa Tantri ${ }^{1}$ \\ Fakultas Ekonomi \\ Universitas Terbuka, Indonesia
}

\author{
Ceicillia Novita Roseline ${ }^{2}$ \\ Fakultas Humaniora dan Bisnis \\ Universitas Pembangunan Jaya, \\ Indonesia
}

\begin{abstract}
Surel : sakina.n.tantri@gmail.com
ABSTRAK

Penelitian ini adalah penelitian kuantitatif mengenai persepsi mahasiswa atas pembelajaran daring di masa pandemi COVID19. Tujuan dari penelitian ini adalah untuk menguji model hubungan antara jenis kelamin, Stress, dan kepuasan dari mahasiswa akuntansi di Indonesia terhadap pembelajaran daring selama masa pandemi COVID-19. Metode yang digunakan dalam penelitian kuantitatif ini adalah metode survey dengan menggunakan sampel mahasiswa akuntansi di beberapa universitas di Indonesia. Jumlah sampel pada penelitian ini adalah 84 mahasiswa, yang didapat melalui teknik pengambilan sampel yaitu purposive convenience sampling. Hasil penelitian ini mengkonfirmasi bahwa hanya pengaruh Stress terhadap kepuasan mahasiswa yang ditemukan signifikan, sedangkan jenis kelamin tidak mempengaruhi Stress dan kepuasan terhadap pembelajaran daring secara signifikan.
\end{abstract}

Kata Kunci: Jenis Kelamin; Stress; Kepuasan; Daring.

Relationship between Gender, Stress, and Accounting Student Satisfaction with Online Learning in the COVID19 Pandemic Period

\section{ABSTRACT}

This study is a quantitative study on student perceptions of online learning during the COVID-19 pandemic. The purpose of this study was to examine the model of the relationship between gender, Stress, and satisfaction of accounting students in Indonesia towards online learning during the COVID-19 pandemic. The method used in this quantitative research is a survey method using a sample of accounting students at several universities in Indonesia. The number of samples in this study were 84 students, obtained through a sampling technique that is purposive convenience sampling. The results of this study confirmed that only the effect of Stress on student satisfaction was found to be significant, while gender did not significantly affect Stress and satisfaction with online learning.

Keywords: $\quad$ Gender; Stressed; Satisfaction; Online.

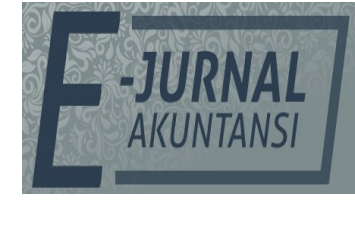

e-ISSN 2302-8556

Vol. 31 No. 7

Denpasar, Juli 2021

Hal. 1783-1797

DOI:

10.24843/EJA.2021.v31.i07.p14

PENGUTIPAN:

Tantri, S.N., \& Roseline, C.N.

(2021). Hubungan Jenis

Kelamin, Stress, dan

Kepuasan Mahasiswa

Akuntansi terhadap

Pembelajaran Daring di Masa

Pandemi COVID-19. E-Jurnal Akuntansi, 31(7), 1783-1797

RIWAYAT ARTIKEL:

Artikel Masuk:

4 Januari 2021

Artikel Diterima:

21 Juli 2021

Artikel dapat diakses : https://ojs.unud.ac.id/index.php/Akuntansi/index 


\section{PENDAHULUAN}

Sistem pembelajaran daring merupakan alternatif paling memungkinkan bagi seluruh pihak yang terkait dalam bidang pendidikan untuk tetap dapat menjalankan kurikulum belajar-mengajar sejak COVID-19 dinyatakan sebagai pandemi. Metode ini tidak terlepas dari pro dan kontra yang mengiringi karena berbagai alasan. Maulana \& Hamidi (2020) berpendapat bahwa pembelajaran daring ini hanya efektif bagi pengajar untuk melakukan penugasan, sedangkan untuk membuat peserta didik memahami materi pembelajaran secara daring dinilai sulit karena minimnya umpan balik maupun interaksi dengan peserta didik. Penerapan pembelajaran dengan metode daring tidak terlepas dari peran masing-masing perguruan tinggi dalam menentukan kebijakan yang mendukung keefektifan metode tersebut. Selain itu, kesiapan institusi dalam memberlakukan metode tersebut juga berpengaruh terhadap implementasi metode pembelajaran daring.

Pendidikan di Indonesia menurut Kerangka Kualifikasi Nasional Indonesia (KKNI) yang diatur dalam Peraturan Presiden Republik Indonesia Nomor 8 Tahun 2012 Tentang Kerangka Kualifikasi Nasional Indonesia, dikelompokkan ke dalam 9 (sembilan) jenjang kualifikasi, dimulai dari jenjang 1 sebagai jenjang terendah sampai dengan jenjang 9 sebagai jenjang tertinggi. Secara konseptual, jenjang tersebut disusun oleh empat parameter utama, yaitu: (a) Ilmu pengetahuan (science), (b) pengetahuan (knowledge), (c) pengetahuan prkatis (know-how), (d) keterampilan (skill), (e) afeksi (affection) dan (f) kompetensi (competency). Jenjang ini berlaku untuk semua program studi, termasuk akuntansi. Dengan demikian, dapat dikatakan bahwa parameter yang digunakan dalam semua program studi secara umum tidak hanya mencakup pengetahuan saja, tetapi juga keterampilan (berhubungan dengan praktik). Nadeak (2020) menyimpulkan bahwa pembelajaran jarak jauh menggunakan media sosial hanya efektif untuk mata kuliah teori dan teori praktik, sedangkan untuk mata kuliah praktik dan kuliah lapangan, tidak efektif karena sifatnya seperti mengontrol dan terkendala jarak serta perlengkapan praktikum. Banyaknya penelitian mengenai efektivitas perkuliahan menggunakan media daring belum diimbangi dengan jumlah peneilitian yang mengkaji dampak psikologis peserta didik dalam hal ini mahasiswa, yang dipengaruhi oleh perkuliahan dengan sistem daring.

Keterbatasan dalam penangkapan materi kuliah peserta didik saat mengikuti pembelajaran secara daring menyebabkan tekanan tersendiri. Kusnayat et al. (2020) menunjukkan bahwa mahasiswa yang siap beradaptasi dengan pembelajaran daring hanya sebesar 60,5 persen, sedangkan sebanyak 59,5 persen mahasiswa merasa keberatan dengan tugas dari dosen. Berdasarkan penelitian tersebut, 92 persen mahasiswa menginginkan perkuliahan dengan metode tatap muka dibandingkan dengan perkuliahan dengan metode daring. Penelitian Maulana \& Iswari, 2020 di bidang pendidikan vokasional menunjukkan bahwa 3 persen mahasiswa yang mengikuti kuliah daring mengalami Stress dengan kategori sangat berat, sedangkan 13 persen mahasiswa mengalami Stress dengan kategori berat. Selain itu, sebanyak 8 persen mahasiswa mengalami Stress kategori sedang, 24 persen mengalami Stress kategori ringan, dan 52 persen mengamai Stress kategori normal. Sementara itu, Nurahaju (2020) meneliti tentang manajemen diri mahasiswa di masa pandemi COVID-19, dan dihasilkan bahwa 80 
mahasiswa yang diteliti memiliki manajemen diri dengan tingkat sedang. Studi empiris mengenai variabel pembelajaran dari rumah dan ketersediaan teknologi informasi oleh Nawangsari (2020) menunjukkan pengaruh positif terhadap pemahaman mahasiswa pada mata kuliah akuntansi. Hal ini sejalan dengan hasil penelitian Maulana \& Hamidi (2020) yang menunjukkan bahwa persepsi mahasiswa terhadap pembelajaran daring pada mata kuliah praktik bersifat positif. Artinya, mahasiswa dapat dikatakan merasa puas terhadap pembelajaran daring.

Kepuasan merupakan perasaan seseorang atas perbandingan antara kinerja produk yang diterima dengan yang diharapkan (Kotler \& Keller, 2009) atau perasaan yang dialami seseorang ketika membandingkan kinerja dan hasil yang diharapkan. Dibandingkan dengan penelitian kepuasan hidup orang dewasa, penelitian tentang kepuasan hidup anak muda telah tertinggal jauh dan kurang representatif terhadap penelitian dengan jangkauan yang luas (Huebner et al., 2012). Oleh karena itu, penelitian saat ini berupaya untuk mengisi kurangnya literatur penelitian tentang kepuasan yang dialami oleh anak muda dengan kebaruan yaitu mengaitkan kepuasan dengan Stress anak muda, dalam hal ini diwakili oleh mahasiswa yang saat ini mengalami perubahan metode pembelajaran secara drastis dari metode tatap muka menjadi daring saat pandemi.

Salah satu faktor yang mempengaruhi kepuasan adalah tingkat Stress (Chung et al., 2017), (Hoboubi et al., 2017), (Pahi et al., 2016), (Manzoor et al., 2011), dan (Ahsan et al., 2009). Stress didefinisikan sebagai tanggapan fisik dan mental ketika karyawan tidak memiliki kemampuan untuk memenuhi tuntutan pekerjaan mereka (Alves, 2005). Beban pekerjaan juga salah satu penyebab adanya gejolak fisik dan nonfisik yang menyebabkan Stress (Vigoda, 2002). Dalam bidang akademik, Stress merupakan masalah yang umum dialami oleh siswa karena adanya tuntutan akademik seperti tugas-tugas dan ujian yang harus dipenuhi (Lumban Gaol, 2016). Selain itu, lingkungan yang baru dihadapi oleh mahasiswa seringkali menyebabkan Stress dalam kehidupannya (Oswalt \& Riddock, 2005). Dengan demikian, tidak menutup kemungkinan bahwa Stress yang dialami oleh mahasiswa juga akan memiliki pengaruh negatif terhadap kepuasan pada aspek pembelajaran daring. Semakin besar tekanan yang dihadapi, maka semakin kecil kepuasan yang dirasakan dalam pekerjaannya. Oleh karena itu, maka hipotesis pertama penelitian ini adalah sebagai berikut.

$\mathrm{H}_{1}$ : Stress berpengaruh negatif terhadap kepuasan mahasiswa akuntansi pada pembelajaran daring.

Stress kerja juga diteliti dalam kaitannya dengan jenis kelamin. Penelitian tentang Stress akademik yang dilakukan pada mahasiswa laki-laki dan perempuan menghasilkan kesimpulan yaitu mahasiswa perempuan mengalami Stress akademik yang lebih rendah dibandingkan mahasiswa laki-laki (Barseli \& Ifdil, 2017). Reschke-Hernández et al. (2017) dalam penelitiannya tentang respon perempuan dan laki-laki terhadap Stress psikologis menggunakan metode eksperimen dengan perlakuan berupa Tier Social Stress Test (TSST) dan Iowa Singing Social Stress Test (I-SSST), mengindikasikan bahwa responden perempuan dan laki-laki menunjukkan tingkat Stress yang sama sebagai respon terhadap kedua perlakuan tersebut. Meskipun demikian, perempuan dan laki-laki menunjukkan respon kortisol yang berbeda, yaitu laki-laki menunjukkan respon 
yang kuat terhadap kedua perlakuan, sedangkan perempuan menunjukkan respon yang lebih lemah. Penelitian lain yang dilakukan oleh Yikealo et al. (2018) menyimpulkan bahwa tingkat Stress mahasiswa tidak berhubungan secara signifikan dengan jenis kelamin. Hal ini sejalan dengan kesimpulan bahwa tidak ada perbedaan signifikan dalam Stress akademik pada responden perempuan dan laki-laki (Stoliker \& Lafreniere, 2015).

Jenis kelamin disebut sebagai salah satu faktor yang secara signifikan mempengaruhi Stress terkait dengan sistem hormonal yang mempengaruhi emosi (Sugiyanto et al., 2020). Perempuan tiga kali lebih berisiko dalam menghadapi Post Traumatic Stress Disorder (PTSD) dibandingkan laki-laki (Olff, 2017). Lebih lanjut, Calvarese (2015) menyimpulkan dalam penelitiannya terkait respon terhadap Stress, bahwa perempuan lebih banyak mengalami depresi, frustrasi, dan kecemasan daripada laki-laki ketika bereaksi terhadap tekanan. Hasil penelitianpenelitian yang diuraikan di atas belum konsisten dan masih perlu diteliti lebih luas. Penelitian ini bermaksud memperkaya literatur untuk mengisi gap ketidakkonsistenan hasil penelitian terkait jenis kelamin dan Stress dalam konteks akademik. Berdasarkan uraian di atas bahwa tingkat Stress dapat dipengaruhi oleh jenis kelamin, maka hipotesis kedua pada penelitian ini adalah sebagai berikut.

$\mathrm{H}_{2}$ : Jenis kelamin berpengaruh terhadap tingkat Stress mahasiswa akuntansi pada pembelajaran daring.

Dalam beberapa penelitian, dikaitkan juga hubungan jenis kelamin dengan kepuasan. Hal ini dibuktikan oleh penelitian Djordjević et al. (2017) pada pekerja di Serbia, yang menyatakan bahwa terdapat perbedaan pada kepuasan kerja secara keseluruhan antara laki-laki dan perempuan. Sharma (2017) menyimpulkan bahwa kepuasan kerja dipengaruhi secara positif oleh nilai organisasi yang dipersepsikan berbeda oleh responden laki-laki dan perempuan. Carvajal \& Popovici (2018) dalam penelitiannya di bidang farmasi, menemukan bahwa meskipun apoteker perempuan secara umum menunjukkan tingkat kepuasan kerja yang lebih tinggi. Joshanloo \& Jovanović (2020) menemukan bahwa perempuan menunjukkan kepuasan hidup yang lebih tinggi daripada laki-laki dalam semua tingkat penghasilan, pendidikan, dan kelompok pekerja.

Perempuan dikatakan memiliki kepuasan yang lebih tinggi dibandingkan laki-laki di sebagian besar negara (Fortin et al., 2015), kecuali di Sub-Sahara Afrika, Eropa Tengah, dan Eropa Timur. Di ketiga wilayah tersebut, laki-laki menunjukkan kepuasan hidup lebih tinggi dibandingkan perempuan. Sementara itu, di Eropa Barat dan Amerika Latin, tidak ditemukan perbedaan kepuasan hidup di antara kedua jenis kelamin laki-laki dan perempuan. Untuk itu, hipotesis ketiga penelitian ini adalah sebagai berikut.

$\mathrm{H}_{3}$ : Jenis kelamin berpengaruh terhadap tingkat kepuasan mahasiswa akuntansi pada pembelajaran daring.

Berdasarkan uraian sebelumnya terkait pengaruh Stress dan kepuasan, dapat dikatakan bahwa jenis kelamin dan Stress dapat mempengaruhi kepuasan secara simultan. Untuk itu, hipotesis keempat pada penelitian ini adalah sebagai berikut.

$\mathrm{H}_{4}$ : Stress dan jenis kelamin berpengaruh terhadap kepuasan mahasiswa akuntansi secara simultan pada pembelajaran daring. 


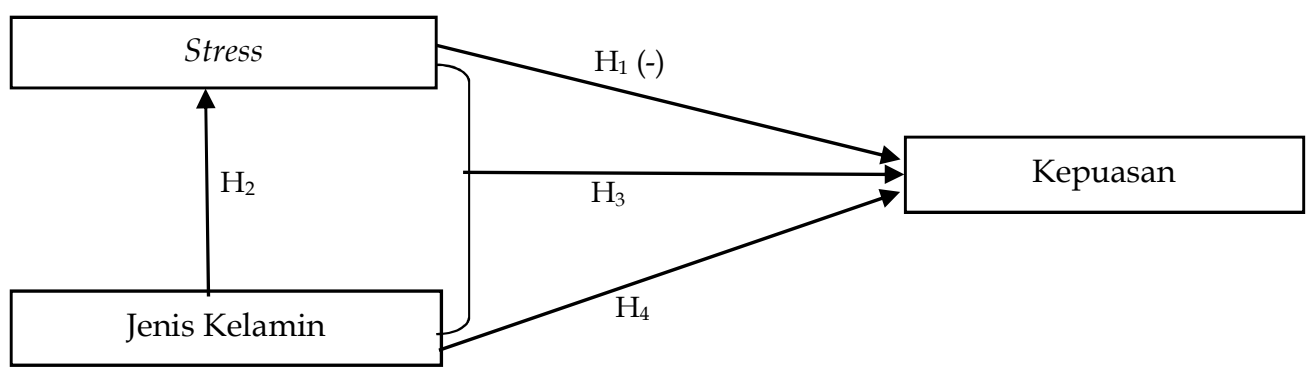

Gambar 1. Model Penelitian

Sumber: Data Penelitian, 2020

\section{METODE PENELITIAN}

Penelitian ini menggunakan data yang dikumpulkan melalui survey. Survey dilakukan secara daring menggunakan media kuesioner dalam bentuk google form kepada target yaitu mahasiswa akuntansi di Indonesia. Sampel yang menjadi target survey berjumlah 540 mahasiswa akuntansi. Hasil akhir sampel yang diperoleh melalui survey tersebut adalah sebanyak 84 sampel. Sampel dipilih menggunakan metode purposive convenience sampling dengan kriteria mahasiswa semua angkatan yang pernah menjalani perkuliahan daring selama minimum tiga bulan. Asumsi peneliti membatasi rentang waktu tiga bulan adalah bahwa dalam tiga bulan, mahasiswa diharapkan sudah melewati tahap penyesuaian dan dianggap telah selesai beradaptasi (telah terbiasa) dengan perkuliahan daring, sehingga penelitian ini diusahakan terhindar dari kemungkinan mahasiswa Stress karena sedang menghadapi penyesuaian dengan perkuliahan daring. Jadi, diasumsikan Stressor berasal dari proses perkuliahan itu sendiri, bukan berasal dari proses penyesuaian/adaptasi. Variabel yang diteliti dalam penelitian ini adalah: (1) Stress mahasiswa akuntansi dalam pembelajaran daring; (2) jenis kelamin mahasiswa akuntansi; (3) kepuasan mahasiswa akuntansi atas pembelajaran daring.

Stress adalah tanggapan fisik dan mental ketika individu tidak memiliki kemampuan untuk memenuhi tuntutan pekerjaan (Alves, 2005). Pada penelitian ini, dapat dikatakan bahwa Stress mahasiswa akuntansi dalam pembelajaran daring merupakan tanggapan fisik dan mental ketika mahasiswa akuntansi menganggap dirinya tidak mampu memenuhi tuntutan pembelajaran daring, atau persepsi atas tekanan yang dialami oleh mahasiswa akuntansi ketika menjalani perkuliahan daring. Stress diukur menggunakan instrumen Depression, Anxiety and Stress Scales (DASS). Sebelumnya, DASS yang terdiri atas 14 pertanyaan telah digunakan dalam penelitian Maulana \& Iswari (2020). Pada penelitian ini, 14 pertanyaan kuesioner tersebut diuji kembali validitas dan reliabilitasnya dan menghasilkan 13 pertanyaan kuesioner yang dapat digunakan untuk mengukur Stress pembelajaran daring.

Jenis kelamin dalam penelitian ini diukur menggunakan variabel dummy dengan simbol 1 untuk laki-laki dan 2 untuk perempuan. Sementara itu, variabel kepuasan yang didefinisikan sebagai perasaan yang dialami seseorang ketika membandingkan kinerja dan hasil yang diharapkan, diukur menggunakan indikator 13 pertanyaan yang diadopsi dari penelitian Maulana \& Hamidi (2020). 
Pada penelitian ini, kepuasan atas pembelajaran daring berarti perasaan mahasiswa ketika membandingkan kinerja dan hasil yang diharapkan dalam pembelajaran daring. Pada penelitian ini, kuesioner kepuasan diuji validitas dan reliabilitasnya dan menghasilkan 8 pertanyaan yang dapat digunakan sebagai indikator kepuasan pembelajaran daring.

Kuesioner penelitian dibagikan pada bulan September 2020 untuk dilakukan pilot test pada 30 mahasiswa. Selanjutnya, dilakukan uji validitas dan reliabilitas, kemudian dibagikan kembali kuesioner yang memenuhi uji tersebut kepada subjek mahasiswa akuntansi di beberapa universitas di Indonesia, seperti Universitas Pembagunan Jaya, Universitas Muhammadiyah Jakarta, Universitas Nasional, Universitas Diponegoro, Universitas Gadjah Mada, dan Universitas Pendidikan Ganesha, dengan cara menyebarkan tautan kuesioner melalui Whatsapp Group. Pengumpulan jawaban kuesioner ditutup pada awal bulan Desember 2020. Pertanyaan kuesioner antara lain terkait dengan demografi responden (usia, jenis kelamin, jenjang pendidikan), lamanya mengikuti perkuliahan daring, domisili, tingkat Stress yang diukur dengan skala likert 1-5 ( 1 =sangat tidak setuju; $2=$ tidak setuju; $3=$ netral; $4=$ setuju; dan $5=$ sangat setuju), dan tingkat kepuasan yang diukur menggunakan skala likert 0-3 $(0=$ tidak pernah; 1 =pernah; 2=sering; dan $3=$ sering sekali). Jawaban dari kuesioner tersebut diseleksi yang memenuhi syarat lalu dihitung total skor DASS dan tingkat kepuasannya untuk diuji statistik. Instrumen penelitian dapat dilihat pada Tabel 1. Untuk menguji hipotesis, digunakan analisis regresi linear dan regresi linear berganda menggunakan perangkat lunak IBM SPSS Statistics versi 26. Adapun rumus regresi pada penelitian ini adalah sevagai berikut.

STRESS $=\alpha+\beta$ JNS_KEL $+\varepsilon$

KEPUASAN $=\alpha+\beta_{1}$ STRESS $+\beta_{2}$ JNS_KEL $+\varepsilon$

\section{Tabel 1. Instrumen Penelitian}

\begin{tabular}{|c|c|c|}
\hline Variabel & Indikator & Sumber \\
\hline \multirow{8}{*}{ Kepuasan } & 1. Kehadiran dosen & Maulana \& \\
\hline & 2. Kejelasan dosen dalam memberikan materi & Hamidi \\
\hline & 3. Tingkat respon dosen & (2020) \\
\hline & 4. Kedalaman pemahaman terhadap materi & \\
\hline & 5. Peningkatan pemahaman terhadap materi & \\
\hline & 6. Kesempatan partisipasi & \\
\hline & 7. Ketersediaan materi & \\
\hline & 8. Ketepatan waktu & \\
\hline \multirow{9}{*}{ Stress } & 1. Kesulitan untuk bersantai & Maulana \& \\
\hline & 2. Kesulitan untuk beristirahat & Iswari \\
\hline & 3. Perasaan mudah tersinggung & (2020) \\
\hline & 4. Perasaan mudah kesal/marah & \\
\hline & 5. Perasaan cemas & \\
\hline & 6. Kesulitan untuk meredakan amarah & \\
\hline & 7. Kesulitan untuk bersabar & \\
\hline & 8. Perasaan gelisah & \\
\hline & 9. Kesulitan menghadapi hambatan & \\
\hline Jenis & & - \\
\hline Kelamin & Laki-laki / Perempuan & \\
\hline
\end{tabular}

Sumber: Data Penelitian, 2020 


\section{HASIL DAN PEMBAHASAN}

Sampel yang menjadi target survey berjumlah 540 mahasiswa akuntansi dan jumlah responden yang menjawab kuesioner terkumpul sebanyak 109 mahasiswa akuntansi. Hal ini menunjukkan response rate sebesar 20,19 persen. Responden berasal dari enam perguruan tinggi di Indonesia, yaitu Universitas Pembagunan Jaya, Universitas Muhammadiyah Jakarta, Universitas Nasional, Universitas Diponegoro, Universitas Gadjah Mada, Universitas Pendidikan Ganesha, dan Sekolah Tinggi Ilmu Ekonomi YKPN. Dari 109 responden tersebut, 25 responden tidak memenuhi syarat karena mengikuti perkuliahan daring kurang dari tiga bulan. Hasil akhir jumlah responden berjumlah 84 mahasiswa yang memenuhi kriteria. Dari 84 responden penelitian ini, 13 mahasiswa berjenis kelamin laki-laki dan 71 mahasiswa berjenis kelamin perempuan. Dari data tersebut, diperoleh data rerata usia 20,89 dengan rentang minimum 18 tahun dan maksimum 26 tahun dari jenjang pendidikan diploma, sarjana, dan magister.

Responden merupakan mahasiswa akuntansi angkatan 2017 hingga angkatan 2020, sehingga data penelitian ini mencakup responden mahasiswa dari empat angkatan, yang didominasi oleh mahasiswa angkatan 2017 (73,8 persen). Saat ini, mahasiswa angkatan 2017 sudah terhitung tiga tahun menjalani perkuliahan, dengan estimasi dua tahun lebih lima bulan untuk perkuliahan luring dan lima hingga enam bulan terakhir untuk perkuliahan daring. Untuk total nilai Stress, diperoleh rentang 1 sampai dengan 39 dengan rerata 16,45 dan deviasi standar 8,007, serta varians 64,106. Total nilai kepuasan menunjukkan rentang 16 sampai 20. Deviasi standar pada total kepuasan adalah 4,590 dan nilai varians adalah sebesar 21,068. Sebagian besar responden melakukan perkuliahan secara daring dari rumah masing-masing menggunakan dua jenis koneksi, yaitu paket data dan wifi dengan sinyal yang cukup kuat dan stabil menurut sebagian besar responden. Hal ini menunjukkan bahwa fasilitas perkuliahan daring cukup memadai di area domisili responden saat menjalani perkuliahan daring (Pulau Jawa dan Bali). Adapun hasil uji statistik deskriptif ditunjukkan pada Tabel 2.

Tabel 2. Hasil Statistik Deskriptif

\begin{tabular}{llllllll}
\hline & & & & & & Std. \\
& $\mathrm{N}$ & Range & Minimum & Maximum & Mean & Deviation & Variance \\
\hline Jenis_Kelamin & 84 & 1 & 1 & 2 & 1,85 & 0,364 & 0,132 \\
Usia & 84 & 8 & 18 & 26 & 20,89 & 1,193 & 1,422 \\
Thn_Masuk & 84 & 3 & 2017 & 2020 & 2017 & 0,827 & 0,684 \\
Stress & 84 & 38 & 1 & 39 & 16,45 & 8,007 & 64,106 \\
Kepuasan & 84 & 20 & 16 & 36 & 25,67 & 4,590 & 21,068 \\
Valid N & 84 & & & & & & \\
(listwise) & & & & & & &
\end{tabular}

Sumber: Data Penelitian, 2020

Melalui Tabel 3, dapat dilihat hasil pengujian hipotesis pertama hingga keempat melalui luaran dari uji regresi linear dan uji regresi linear berganda menggunakan perangkat lunak IBM SPSS versi 26. Dari hasil pengujian hipotesis pertama yang berbunyi Stress berpengaruh negatif terhadap kepuasan mahasiswa akuntansi pada pembelajaran daring, diperoleh nilai $R$-Square sebesar 0,076 . Hal ini menunjukkan bahwa Stress memiliki andil sebesar 7,6 persen dalam menjelaskan kepuasan mahasiswa akuntansi dalam pembelajaran daring. 
Sementara itu, koefisien regresi pada pengujian hipotesis pertama menunjukkan angka -0,164, yang berarti bahwa Stress berpengaruh secara negatif terhadap kepuasan mahasiswa akuntansi pada pembelajaran daring.

Untuk mengetahui apakah pengaruh tersebut signifikan, maka dapat dilihat $p$-value yang dihasilkan, yang pada pengujian ini diperoleh nilai 0,010 $(\mathrm{p}<0,05)$ yang berarti signifikan. Maka dari itu, dapat disimpulkan hipotesis pertama terdukung. Keterdukungan hipotesis pertama menunjukkan bahwa meskipun kontribusi Stress dalam mempengaruhi kepuasan mahasiswa akuntansi dalam pembelajaran daring relatif kecil (7,6 persen), tetapi, pengaruh yang dihasilkan signifikan. Sementara itu, 92,4 persen pengaruh terhadap kepuasan mahasiswa akuntansi dijelaskan oleh faktor lain di luar faktor yang diuji dalam penelitian ini. Temuan ini mengkonfirmasi penelitian-penelitian sebelumnya terkait hubungan Stress dan kepuasan dalam dunia kerja, yaitu (Chung et al. 2017), (Hoboubi et al. 2017), (Pahi et al. 2016), (Manzoor et al. 2011) dan (Ahsan et al. 2009).

Literatur yang meneliti Stress dalam kaitannya dengan kepuasan di dunia pendidikan masih jarang dilakukan. Maka dari itu, hasil penelitian ini dapat digunakan sebagai dasar pemikiran penelitian selanjutnya mengenai Stress dan kepuasan akademik terkait pembelajaran daring di kalangan mahasiswa perguruan tinggi, dengan logika yang sama, bahwa tekanan-tekanan yang dipersepsikan oleh mahasiswa pada saat menjalani perkuliahan daring dapat menurunkan persepsi positif berupa kepuasan atas metode pembelajaran itu sendiri. Oleh karena itu, model hubungan Stress dengan kepuasan dapat dikatakan relevan untuk digunakan dalam penelitian dalam konteks yang berbeda, dalam hal ini konteks bidang pekerjaan dan akademik. Meskipun demikian, pengujian robustness tetap harus dilakukan, mengingat kondisi lingkungan saat ini yang cenderung cepat berubah, terutama dengan adanya pandemi COVID-19 yang membuat orang merasakan banyak tekanan dari banyak faktor, di luar lingkungan akademik dan juga pekerjaan.

Tabel 3. Hasil Uji Hipotesis

\begin{tabular}{|c|c|c|c|c|c|}
\hline \multirow{2}{*}{\multicolumn{2}{|c|}{ Model }} & \multirow[b]{2}{*}{ R-Square } & \multirow{2}{*}{$\frac{\text { Koefisien }}{\text { B }}$} & \multirow[b]{2}{*}{$\mathrm{t}$} & \multirow[b]{2}{*}{ Sig. } \\
\hline & & & & & \\
\hline \multirow[t]{2}{*}{1} & (Constant) & & 8,412 & 1,878 & 0,006 \\
\hline & Jenis_Kelamin & 0,039 & 4,358 & 1,829 & 0,007 \\
\hline \multicolumn{6}{|c|}{ Variabel dependen: Stress } \\
\hline \multirow[t]{3}{*}{1} & (Constant) & & 27,103 & 10,490 & 0,000 \\
\hline & Jenis_Kelamin & $0,000\left(^{*}\right)$ & 0,685 & 0,499 & 0,619 \\
\hline & Stress & $0,076\left(^{*}\right)$ & $-0,164$ & $-2,631$ & 0,010 \\
\hline
\end{tabular}

$\left.{ }^{*}\right)$ Parsial (R-Square simultan: 0,079)

Variabel dependen: Kepuasan

Sumber: Data Penelitian, 2020

Dari 84 mahasiswa akuntansi, sebanyak 45,2 persen mengalami Stress dengan kategori normal, sedangkan 13,1 persen mengalami Stress kategori ringan, 28,6 persen termasuk kategori sedang, dan 10,7 persen termasuk Stress kategori berat. Sisanya, 2,4 persen atau sebanyak 2 orang mengalami Stress dengan kategori sangat berat. Berdasarkan tabel 3 tentang pengaruh jenis kelamin terhadap Stress, diperoleh nilai $R$-Square sebesar 0,039, yang artinya jenis kelamin dapat menjelaskan tingkat Stress yang dialami oleh mahasiswa akuntansi sebesar 3,9 
persen. Sementara itu, 96,1 persen faktor lain yang menjelaskan Stress adalah faktor-faktor luar yang tidak diuji dalam penelitian ini. Koefisien regresi diperoleh nilai sebesar 4,358 dengan angka positif, yang berarti bahwa pengaruh jenis kelamin terhadap Stress adalah positif. Jika jenis kelamin laki-laki diwakili oleh angka 1, dan perempuan diwakili oleh angka 2, maka dapat dikatakan bahwa mahasiswa perempuan cenderung memiliki tingkat Stress yang lebih tinggi. Angka signifikansi yang dihasilkan untuk pengujian hipotesis kedua ini adalah $0,071$ ( $p>0,05)$, maka pengaruh jenis kelamin terhadap Stress tidak signifikan pada level konfidensi 95 persen. Dengan demikian, hipotesis kedua tidak terdukung.

Jenis kelamin yang berbeda ditemukan tidak berpengaruh terhadap Stress pada perkuliahan daring dalam penelitian ini. Tidak adanya pengaruh jenis kelamin terhadap Stress ini bisa disebabkan oleh adanya Stressor yang sama. Penelitian terdahulu yang menyatakan bahwa jenis kelamin yang berbeda merespon Stress dengan berbeda pula (Olff, 2017) tidak dapat dikonfimasi oleh penelitian ini. Penelitian lain yang juga bertentangan dengan hasil penelitian ini adalah Kowal et al. (2020) yang menyimpulkan bahwa tingkat Stress yang lebih tinggi berhubungan dengan usia yang lebih muda, berjenis kelamin wanita, tingkat pendidikan yang lebih rendah, lajang, tinggal dengan lebih banyak anak, dan tinggal di negara yang memiliki situasi COVID-19 yang lebih parah. Sementara itu, penelitian yang terkonfirmasi dengan hasil penelitian ini adalah Yikealo et al. (2018) dan Stoliker \& Lafreniere (2015) yang menyimpulkan bahwa tingkat Stress tidak berhubungan dengan jenis kelamin. Di Indonesia sendiri, Maulana \& Iswari (2020) menyatakan jenis kelamin sebagai salah satu faktor yang mempengaruhi Stress di bidang akademik.

Berdasarkan hasil uji statistik lanjutan pada Tabel 4, ditemukan bahwa tidak terdapat perbedaan signifikan dalam tingkat Stress pada mahasiswa laki-laki dan perempuan. Pada pengujian hipotesis kedua, digunakan angka skor total Stress sebagai parameter variabel Stress. Dalam pengujian lanjutan, peneliti mencoba mengubah parameter Stress dari angka total berskala rasio menjadi kategorikal dengan membagi skor total Stress menjadi lima macam kategori menurut interpretasi DASS, yaitu Stress kategori normal, ringan, sedang, berat, dan sangat berat, yang disimbolkan dengan 1=normal; 2=ringan; 3=sedang; 4=berat; dan $5=$ sangat berat. Dari pengujian lanjutan ini, dihasilkan temuan adanya perbedaan kategori Stress yang signifikan di antara responden laki-laki dan perempuan. Hal ini ditunjukkan dengan angka signifikansi (Sig. 2-tailed) bernilai 0,035 ( $\mathrm{p}<0,05)$ pada baris kategori Stress bagian equal variance not assumed.

Berdasarkan jawaban responden atas kuesioner terkait Stress pada penelitian ini, skor terbesar yang diperoleh adalah pada pernyataan saya menemukan diri saya mudah merasa kesal. Kesal yang dirasakan oleh mahasiswa ini bisa disebabkan oleh banyak faktor yang terkait perkuliahan daring, misalnya terkait dengan kendala yang dihadapi oleh mahasiswa saat perkuliahan. Berdasarkan jawaban mahasiswa dalam pertanyaan terbuka di kuesioner survey yang dibagikan, apa kendala yang anda hadapi pada saat pelaksanaan perkuliahan daring? maka jawabannya antara lain diskusi yang monoton, tugas yang banyak, bahan materi yang terbatas, respon dosen yang lambat, dan perkuliahan yang tidak tepat waktu. 
TANTRI, S.N., \& ROSELINE, C.N. HUBUNGAN JENIS KELAMIN...

Tabel 4. Hasil Uji Beda Jenis Kelamin dan Stress

\begin{tabular}{llccccc}
\hline & & $\mathrm{F}$ & Sig. & $\mathrm{t}$ & $\mathrm{df}$ & Sig. (2-tailed) \\
\hline \multirow{2}{*}{ Stress (Total) } & Equal variances assumed & 0,744 & 0,391 & $-1,829$ & 82 & 0,071 \\
& Equal variances not assumed & & & -2.011 & 18.283 & 0,059 \\
Stress (Kategori) & Equal variances assumed & 3,843 & 0,053 & $-1,969$ & 82 & 0,052 \\
& Equal variances not assumed & & & $-2,267$ & 19,258 & 0,035 \\
\hline
\end{tabular}

Sumber: Data Penelitian, 2020

Terkait tugas yang banyak khususnya dalam bidang akuntansi dapat disebabkan antara lain oleh kurikulum jurusan akuntansi yang memang pada dasarnya ada kewajiban untuk menekankan pada praktik di mata kuliah tertentu. Dalam hal ini, komposisi mata kuliah teori dan praktikum harus terpenuhi. Materi praktikum yang idealnya dilakukan di laboratorium jadi mengalami keterbatasan media dan menjadi tidak maksimal dalam proses penyampaian materi dan penyerapan ilmunya oleh mahasiswa. Pemberian tugas yang banyak mungkin saja dapat menjadi sebuah efek tidak adanya tatap muka langsung dalam mata kuliah yang semestinya bersifat praktikal, yang hal ini menyebabkan mahasiswa mengalami tekanan.

Temuan penelitian ini mengkonfirmasi bahwa tidak terdapat pengaruh jenis kelamin terhadap stres akademik. Hal ini sesuai dengan hasil penelitian Hafifah et al. (2017) yang menyimpulkan bahwa tidak terdapat perbedaan antara mahasiswa keperawatan laki-laki dan perempuan dalam merespons Stress. Hal ini dikarenakan adanya kesamaan Stressor yang diterima diterima oleh mahasisa lakilaki dan perempuan. Oleh karena itu, model hubungan jenis kelamin dan Stress perlu diuji kembali menggunakan banyak konteks misalnya di usia dewasa (bukan mahasiswa atau pemuda) di Indonesia, dengan beraneka ragam budaya organisasi dan jenis pekerjaan, yang mungkin menyebabkan perbedaan persepsi tingkat Stress yang dialami.

Pengujian selanjutnya dilakukan untuk mengetahui pengaruh jenis kelamin terhadap kepuasan mahasiswa akuntansi atas pembelajaran daring (hipotesis 3). Pengujian menghasilkan $R$-Square 0,000 yang artinya jenis kelamin hampir tidak memberikan kontribusi untuk mempengaruhi kepuasan. Untuk koefisien regresi yang bernilai positif $(0,685)$ berarti mahasiswa perempuan cenderung mengalami kepuasan yang tinggi. Nilai siignifikansi yang dihasilkan melalui uji statistik juga menunjukkan bahwa pengaruh jenis kelamin terhadap kepuasan tidak signifikan $(0,619 ; \mathrm{p}>0,05)$. Untuk itu, hipotesis ketiga tidak terdukung. Hal ini juga berarti bahwa tingkat kepuasan dapat dikatakan berada dalam level yang sama antara mahasiswa laki-laki dan perempuan ketika menjalani perkuliahan. Hasil penelitian ini juga tidak mampu mengkonfirmasi penelitian yang menyimpulkan adanya pengaruh perbedaan jenis kelamin terhadap kepuasan (Carvajal \& Popovici, 2018), (Djordjević et al., 2017), dan (Sharma, 2017)).

Pengujian lanjutan dilakukan untuk mengetahui apakah ada perbedaan signifikan pada tingkat kepuasan di antara mahasiswa laki-laki dan perempuan, yang ditunjukkan pada Tabel 5. Signifikansi sebesar 0,984 menunjukkan tidak adanya perbedaan signifikan di antara mahasiswa laki-laki dan perempuan dalam tingkat kepuasan perkuliahan daring.

Ditinjau dari pembahasan hipotesis pertama hingga ketiga bahwa jenis kelamin berpengaruh positif (tidak signifikan) terhadap Stress dan berpengaruh 
positif (tidak signifikan) juga terhadap kepuasan, sementara Stress berpengaruh negatif signifikan terhadap kepuasan, maka hal ini menciptakan pandangan lain tentang model untuk menggambarkan apakah perempuan cenderung mudah untuk mempersepsikan Stress dan kepuasan. Penelitian lebih lanjut diperlukan untuk menganalisis faktor-faktor di luar yang diteliti saat ini untuk menjelaskan kembali model yang tepat untuk pengaruh jenis kelamin terhadap Stress dan kepuasan menggunakan model moderasi. Adapun faktor yang mungkin melatarbelakangi mengapa perempuan cenderung mudah untuk mempersepsikan Stress dan kepuasan adalah karena perempuan lebih menggunakan perasaan dibandingkan laki-laki, sehingga jika secara psikologis mengalami gangguan atau tekanan akan lebih mudah dalam menunjukkan persepsinya.

Tabel 5. Hasil Uji Beda Jenis Kelamin dan Kepuasan

\begin{tabular}{llccccc}
\hline & & $\mathrm{F}$ & Sig. & $\mathrm{t}$ & $\mathrm{df}$ & Sig. (2-tailed) \\
\hline \multirow{2}{*}{ Kepuasan } & Equal variances assumed & 0,488 & 0,487 & 0,022 & 82 & 0,983 \\
& Equal variances not assumed & & & 0,021 & 16,041 & 0,984 \\
\hline
\end{tabular}

Sumber: Data Penelitian, 2020

Pengujian hipotesis keempat tentang pengaruh simultan Stress dan jenis kelamin terhadap kepuasan mahasiswa akuntansi pada pembelajaran daring menghasilkan $R$-Square 0,079 yang berarti bahwa variabel Stress dan jenis kelamin berkontribusi sebesar 7,9 persen dalam menjelaskan kepuasan pembelajaran daring secara simultan. Signifikansi pengujian simultan dapat dilihat pada Tabel 6. Pada Tabel 6, terlihat bahwa nilai signifikansi pada pengujian tersebut adalah $0,036(\mathrm{p}<0,05)$ yang artinya pengaruh simultan Stress dan jenis kelamin terhadap kepuasan adalah signifikan.

Tabel 6. Hasil Uji Simultan

\begin{tabular}{llccccc}
\hline Model & & Sum of Squares & $d f$ & Mean Square & F & Sig. \\
\hline 1 & Regression & 137,666 & 2 & 68,833 & 3,461 & $0,036^{\mathrm{b}}$ \\
& Residual & 1611,000 & 81 & 19,889 & & \\
& Total & 1748,667 & 83 & & &
\end{tabular}

a. Variabel Dependen: Kepuasan

b. Predictors: (Constant), Stress, Jenis Kelamin

Sumber: Data Penelitian, 2020

Pengaruh simultan Stress dan jenis kelamin ditemukan signifikan terhadap kepuasan pembelajaran daring pada mahasiswa akuntansi. Hal ini menunjukkan bahwa secara bersama-sama, kedua variabel tersebut dapat mempengaruhi kepuasan, meskipun jika diukur secara parsial tidak berpengaruh. Eksplorasi kemudian dilakukan dalam penelitian ini untuk mengetahui faktor apa yang dapat mempengaruhi kepuasan selain tingkat Stress, dan diperoleh hasil bahwa tahun masuk kuliah berpengaruh terhadap kepuasan pembelajaran daring.

Tabel 7. Hasil Uji Regresi Linear Berganda dengan Tambahan Variabel

\begin{tabular}{llrrr}
\hline Model & & B & \multicolumn{1}{c}{ t } & \multicolumn{1}{c}{ Sig. } \\
\hline 1 & (Constant) & $-2464,591$ & $-2,029$ & 0,046 \\
& Usia & $-0,558$ & $-1,370$ & 0,175 \\
& Tahun Masuk & 1,241 & 2,064 & 0,042
\end{tabular}

Sumber: Data Penelitian, 2020 
Berdasarkan Tabel 7, diperoleh angka signifikansi sebesar 0,042 $(<0,05)$ yang berarti pengaruh tahun masuk terhadap kepuasan pembelajaran daring adalah signifikan, dengan angka koefisien 1,241 yang bernilai positif. Berarti, pengaruh tahun masuk kuliah terhadap kepuasan adalah positif signifikan. Semakin muda agkatan masuk mahasiswa akuntansi, maka semakin tinggi kepuasan yang dirasakan atas pembelajaran daring. Hal ini mungkin terjadi karena mahasiswa angkatan lama telah terbiasa dengan metode perkuliahan tatap muka. Oleh karena itu, adaptasi dengan perkuliahan daring menjadi sebuah tantangan tersendiri. Tantangan tersebut bisa lebih berat dirasakan oleh mahasiswa angkatan 2017 dibandingkan dengan angkatan 2018 sampai dengan 2020 yang belum lama menjalani perkuliahan luring sehingga proses adaptasinya lebih mudah. Meskipun demikian, dikarenakan terbatasnya literatur yang relevan untuk menjelaskan hubungan tahun masuk kuliah dengan kepuasan akademik, diharapkan pada peneliti selanjutnya untuk dapat mengeksplorasi keterkaitan antara hubungan tersebut berdasarkan teori yang relevan.

\section{SIMPULAN}

Hasil penelitian ini menjawab penelitian Huebner et al. (2012) terkait kebutuhan penelitian terkait kepuasan di kalangan anak muda dengan menggunakan konteks pendidikan akuntansi yang dilakukan secara daring. Penelitian ini menunjukkan bahwa kepuasan mahasiswa akuntansi dalam menjalani perkuliahan daring dipengaruhi oleh Stress, dan tidak dipengaruhi oleh jenis kelamin mahasiswa. Berdasarkan hasil penelitian ini, maka dapat disimpulkan bahwa Stress mempengaruhi kepuasan pembelajaran daring, sedangkan jenis kelamin mahasiswa akuntansi tidak mempengaruhi Stress dan kepuasan dalam pembelajaran daring. Sementara itu, Stress dan jenis kelamin mahasiswa akuntani berpengaruh terhadap kepuasan pembelajaran daring secara simultan, tetapi tidak secara parsial.

Penelitian ini memiliki keterbatasan dalam hal sampel yang berasal dari area dan budaya yang relatif homogen karena berasal dari Jabodetabek, Jawa Tengah, D.I. Yogyakarta, dan Bali. Untuk cakupan populasi mahasiswa akuntansi seluruh Indonesia yang memiliki beraneka macam budaya, perlu dilakukan penelitian yang lebih ekstensif dan mengambil time frame yang lebih panjang. Eksplorasi mendalam untuk memperkuat validitas internal juga dapat menjadi alternatif pengembangan penelitian selanjutnya. Selain itu, perlu dikembangkan juga mengenai tingkat Stress dan kepuasan terutama dalam bidang akademik karena saat ini, sektor pendidikan atau akademik adalah salah satu sektor yang mengalami dampak besar karena pandemic COVID-19. Lebih jauh lagi, penelitian selanjutnya diharapkan dapat mengembangkan penelitian ini menggunakan ukuran Stress dan kepuasan yang lebih advanced misalnya mengukur attitude atau behavior, mengingat penelitian ini hanya sebatas mengukur persepsi mahasiswa.

\section{REFERENSI}

Ahsan, N., Abdullah, Z., Fie, D. Y. G., \& Alam, S. S. (2009). A study of job Stress on job satisfaction among university staff in Malaysia: Empirical study. European Journal of Social Sciences, 8(1), 121-131.

Alves, S. L. (2005). A study of occupational Stress, scope of practice, and 
collaboration in nurse anesthetists practicing in anesthesia care team settings. AANA Journal, 73(6), 443-452.

Barseli, M., \& Ifdil, I. (2017). Konsep Stres Akademik Siswa. Jurnal Konseling Dan Pendidikan, 5(3), 143. https:/ / doi.org/10.29210/119800

Calvarese, M. (2015). The effect of gender on Stress factors: An exploratory study among university students. Social Sciences, 4(4), 1177-1184. https://doi.org/10.3390/socsci4041177

Carvajal, M. J., \& Popovici, I. (2018). Gender, age, and pharmacists' job satisfaction. Pharmacy Practice, 16(4), 1-11. https:// doi.org/10.18549/PharmPract.2018.04.1396

Chung, E. K., Jung, Y., \& Sohn, Y. W. (2017). A moderated mediation model of job Stress, job satisfaction, and turnover intention for airport security screeners. Safety Science, 98, 89-97. https://doi.org/10.1016/j.ssci.2017.06.005

Djordjević, B., Ivanović-Djukić, M., \& Lepojević, V. (2017). Relationship of Ages and Gender of the Employees in Organisations in the Republic of Serbia and Their Job Satisfaction. Economic Themes, 55(2), 263-280. https://doi.org/10.1515/ethemes-2017-0015

Fortin, N., Helliwell, J. F., \& Wang, S. (2015). How does subjective well-being vary around the world by gender and age? In World Happiness Report (Vol. 3, pp. 42-74).

Hafifah, N., Widiani, E., \& Rahayu, W. H. (2017). Perbedaan Stres Akademik Pada Mahasiswa Program Studi Ilmu Keperawatan Berdasarkan Jenis Kelamin Di Fakultas Kesehatan Universitas Tribhuwana Tunggadewi Malang. Nursing News, 2, 220-229.

Hoboubi, N., Choobineh, A., Kamari Ghanavati, F., Keshavarzi, S., \& Akbar Hosseini, A. (2017). The Impact of Job Stress and Job Satisfaction on Workforce Productivity in an Iranian Petrochemical Industry. Safety and Health at Work, 8(1), 67-71. https://doi.org/10.1016/j.shaw.2016.07.002

Huebner, E. S., Zullig, K. J., \& Saha, R. (2012). Factor Structure and Reliability of an Abbreviated Version of the Multidimensional Students' Life Satisfaction Scale. Child Ind Res, 5, 651-657.

Joshanloo, M., \& Jovanović, V. (2020). The relationship between gender and life satisfaction: analysis across demographic groups and global regions. Archives of Women's Mental Health, 23(3), 331-338. https://doi.org/10.1007/s00737019-00998-w

Kotler, P., \& Keller, K. L. (2009). Marketing Management (13th ed.). Upper Saddle River, N.J. : Pearson Prentice Hall.

Kowal, M., Coll-Martín, T., Ikizer, G., Rasmussen, J., Eichel, K., Studzińska, A., Koszałkowska, K., Karwowski, M., Najmussaqib, A., Pankowski, D., Lieberoth, A., \& Ahmed, O. (2020). Who is the Most Stressed During the COVID-19 Pandemic? Data From 26 Countries and Areas. Applied Psychology: Health and Well-Being, 1-21. https:// doi.org/10.1111/aphw.12234

Kusnayat, A., Sumarni, N., Mansyur, A. S., Zaqiah, Q. Y., \& Bandung, U. T. (2020). Pengaruh Teknologi Pembelajaran Kuliah Online Di Era Covid-19 Dan Dampaknya Terhadap Mental Mahasiswa. EduTeach: Jurnal Edukasi Dan Teknologi Pembelajaran, 1(2), 153-165.

Lumban Gaol, N. T. (2016). Teori Stres: Stimulus, Respons, dan Transaksional. 
Buletin Psikologi, 24(1), 1. https://doi.org/10.22146/bpsi.11224

Manzoor, M. U., Usman, M., Naseem, M. A., \& Shafiq, M. M. (2011). among Universities Faculty in Lahore, Pakistan. Global Journal Of Management And Business Research, 11(9), 12-16.

Maulana, H. A., \& Hamidi, M. (2020). Persepsi Mahasiswa terhadap Pembelajaran Daring pada Mata Kuliah Praktik di Pendidikan Vokasi. Equilibrium: Jurnal Pendidikan, 8(2), 224-231. https://doi.org/10.26618/equilibrium.v8i2.3443

Maulana, H. A., \& Iswari, R. D. (2020). Analisis Tingkat Stres Mahasiswa Terhadap Pembelajaran Daring Pada Mata Kuliah Statistik Bisnis di Pendidikan Vokasi. Jurnal Ilmiah Kependidikan, 14(1), 17-30.

Nadeak, B. (2020). The effectiveness of distance learning using social media during the pandemic period of covid-19: A case in universitas kristen indonesia. International Journal of Advanced Science and Technology, 29(7), 1764-1772. https://www.scopus.com/inward/record.uri?partnerID=HzOxMe3b\&scp= 85085285142\&origin=inward

Nawangsari, A. T. (2020). AkuntansI : Jurnal Akuntansi Integratif COVID19 (Studi Empiris Mahasiswa Akuntansi Di Jawa Timur ) Ajeng Tita Nawangsari. 6(2), 7186.

Nurahaju, R. (2020). Gambaran Manajemen Diri Mahasiswa Saat Pandemi Covid19 Ditinjau dari Jenis Kelamin. Jurnal Ilmiah Kependidikan, XIV(1), 31-43.

Olff, M. (2017). Sex and gender differences in post-traumatic Stress disorder: an update. European Journal of Psychotraumatology, 8(sup4), 1351204. https:// doi.org/10.1080/20008198.2017.1351204

Oswalt, S. B., \& Riddock, C. C. (2005). What to Do About Being Overwhelmed: Graduate Students, Stress and University Services. 24-44.

Pahi, M. H., Hamid, K. A., \& Khalid, N. (2016). Save talent of banking sector of Pakistan: Mediating job satisfaction between job Stress and employee turnover intention. International Review of Management and Marketing, 6(3), 617-624.

Peraturan Presiden Republik Indonesia Nomor 8 Tahun 2012 Tentang Kerangka Kualifikasi Nasional Indonesia, (2012).

Reschke-Hernández, A. E., Okerstrom, K. L., Bowles Edwards, A., \& Tranel, D. (2017). Sex and Stress: Men and women show different cortisol responses to psychological Stress induced by the Trier social Stress test and the Iowa singing social Stress test. Journal of Neuroscience Research, 95(1-2), 106-114. https:// doi.org/10.1002/jnr.23851

Sharma, P. (2017). Organizational culture as a predictor of job satisfaction: The role of age and gender. Management (Croatia), 22(1), 35-48. https:// doi.org/10.30924/mjcmi/2017.22.1.35

Stoliker, B., \& Lafreniere, K. (2015). The Influence of Perceived Stress, Loneliness, and Learning Burnout on University Students' Educational Experience. College Student Journal, 49(1), 146-160.

Sugiyanto, E. P., Prasetyo, C. H., \& Pramono, W. H. (2020). Indonesian Journal of Global Health Research. Indonesian Journal of Global Health Research, 2(4), 309314. http://jurnal.globalhealthsciencegroup.com/index.php/IJGHR

Vigoda, E. (2002). Stress-related aftermaths to workplace politics: The relationships among politics, job diStress, and aggressive behavior in organizations. Journal 
of Organizational Behavior, 23(5), 571-591. https://doi.org/10.1002/job.160 Yikealo, D., Yemane, B., \& Karvinen, I. (2018). The Level of Academic and Environmental Stress among College Students: A Case in the College of Education. Open Journal of Social Sciences, 06(11), 40-57. https:// doi.org/10.4236/jss.2018.611004 